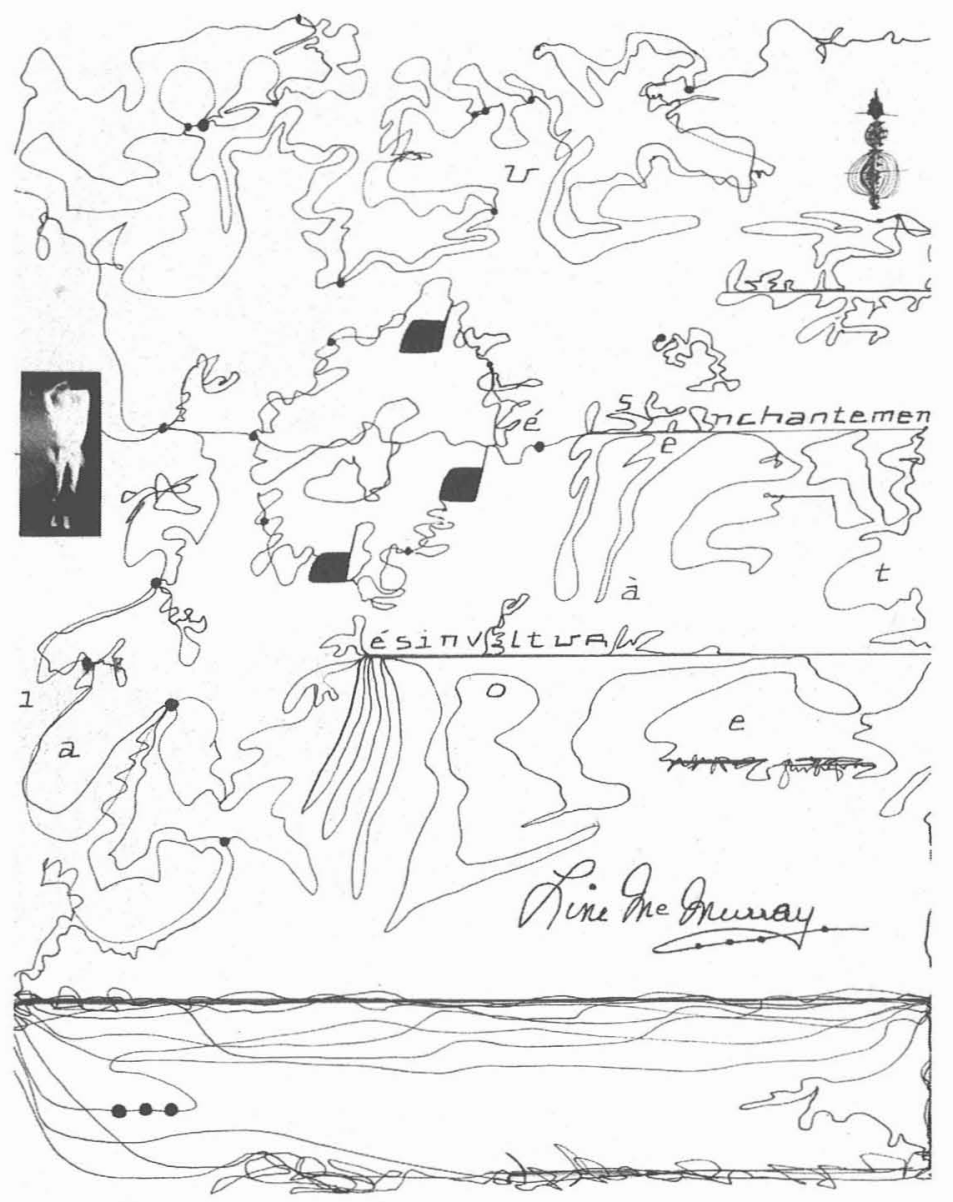

\title{
Du Désenchantement à la Désinvolture
}

\section{Impunity: Distance as an Ethic}

LINE MC MURRAY

Translation: Richard Lebeau / Louise Ladouceur 


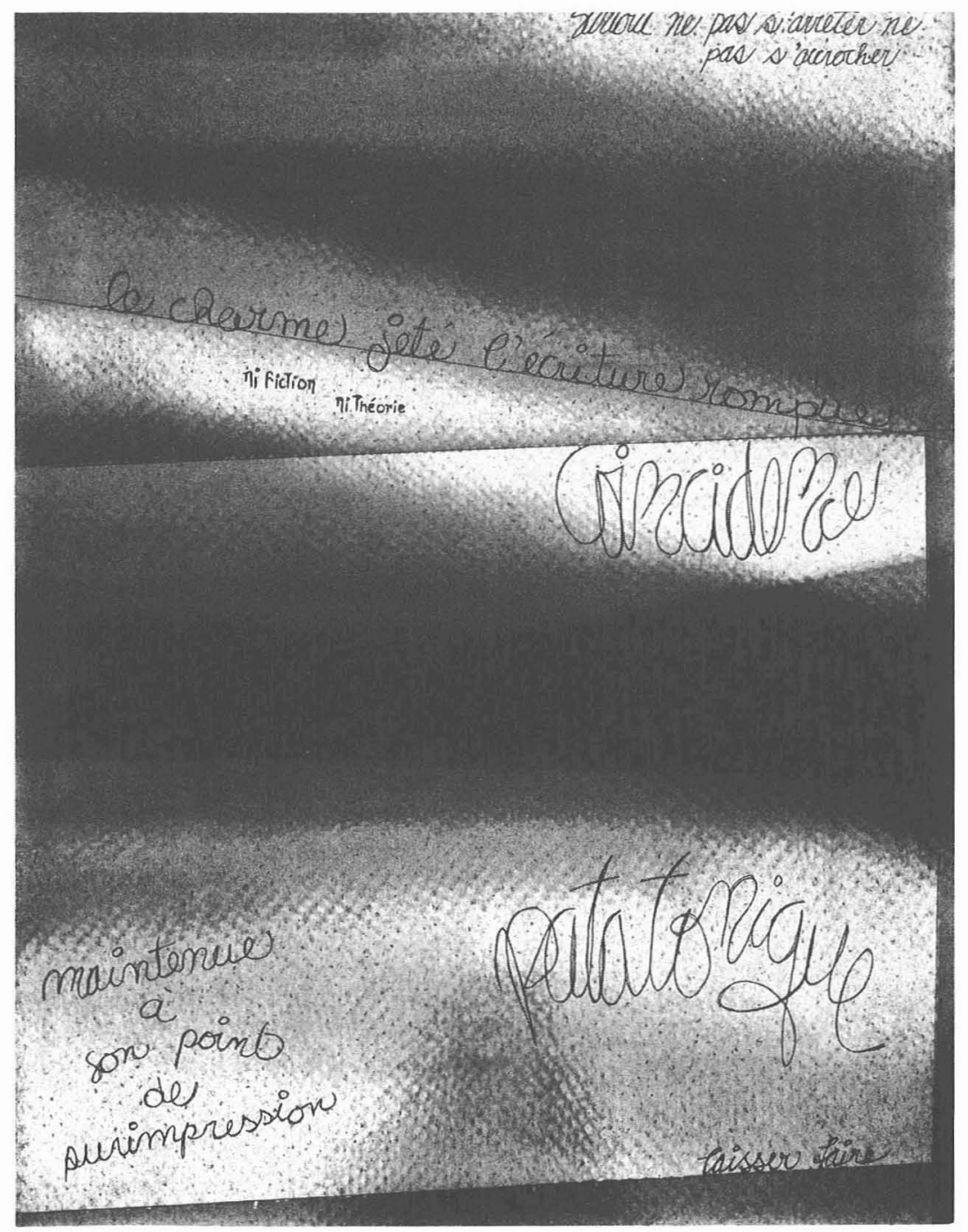

surtout ne pas s'arrêter ne ' pas s'accrocher ' le charme jeté l'écriture rompue' ni fiction ni théorie ' coïncidence ' patatonique / maintenue à son point de surimpression / laisser faire

above all not to stop not / to hold on to / the spell cast the written word breaks free / neither fiction nor theory / coincidence / patatonic / maintained at its point of superimposition / let go 


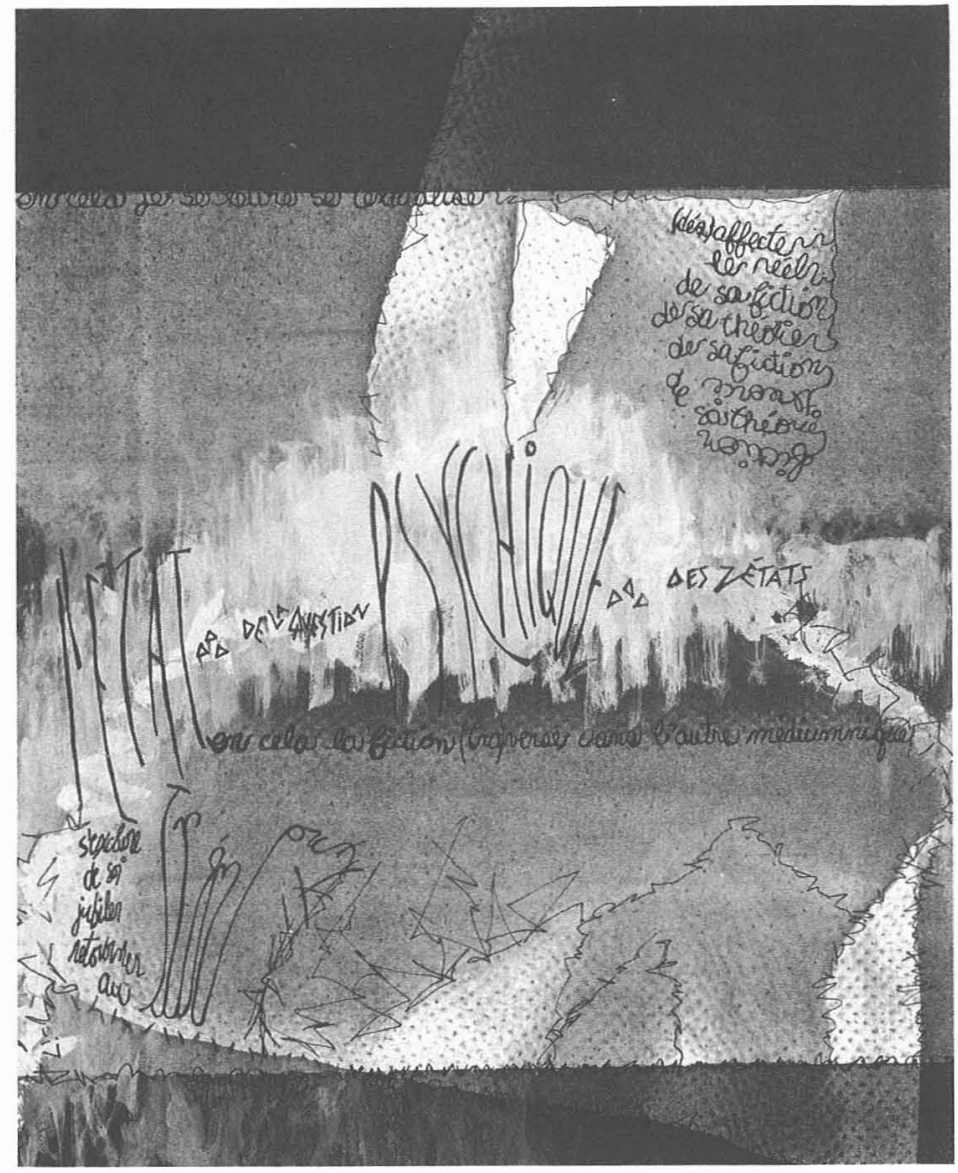

en cela je se retire se textualise / (dés) affecte le réel de sa fiction de sa théorie de sa fiction-théorie de sa théorie-fiction / l'état ... de la question psychique ... des zétats ... "en cela la fiction (tra)verse dans l'autre médiumnique / s'exclure de soi jubiler retourner au trémoux

therein withdrawing the i dissolves into the text / altered (by) the reality of its fiction its theory its

fiction-theory its theory-fiction / the state ... of the psychic question ... destates ... / therein fiction (tra)verses its mediumlike counterpart / self-excluded from oneself exulted shivering back to the swirl 


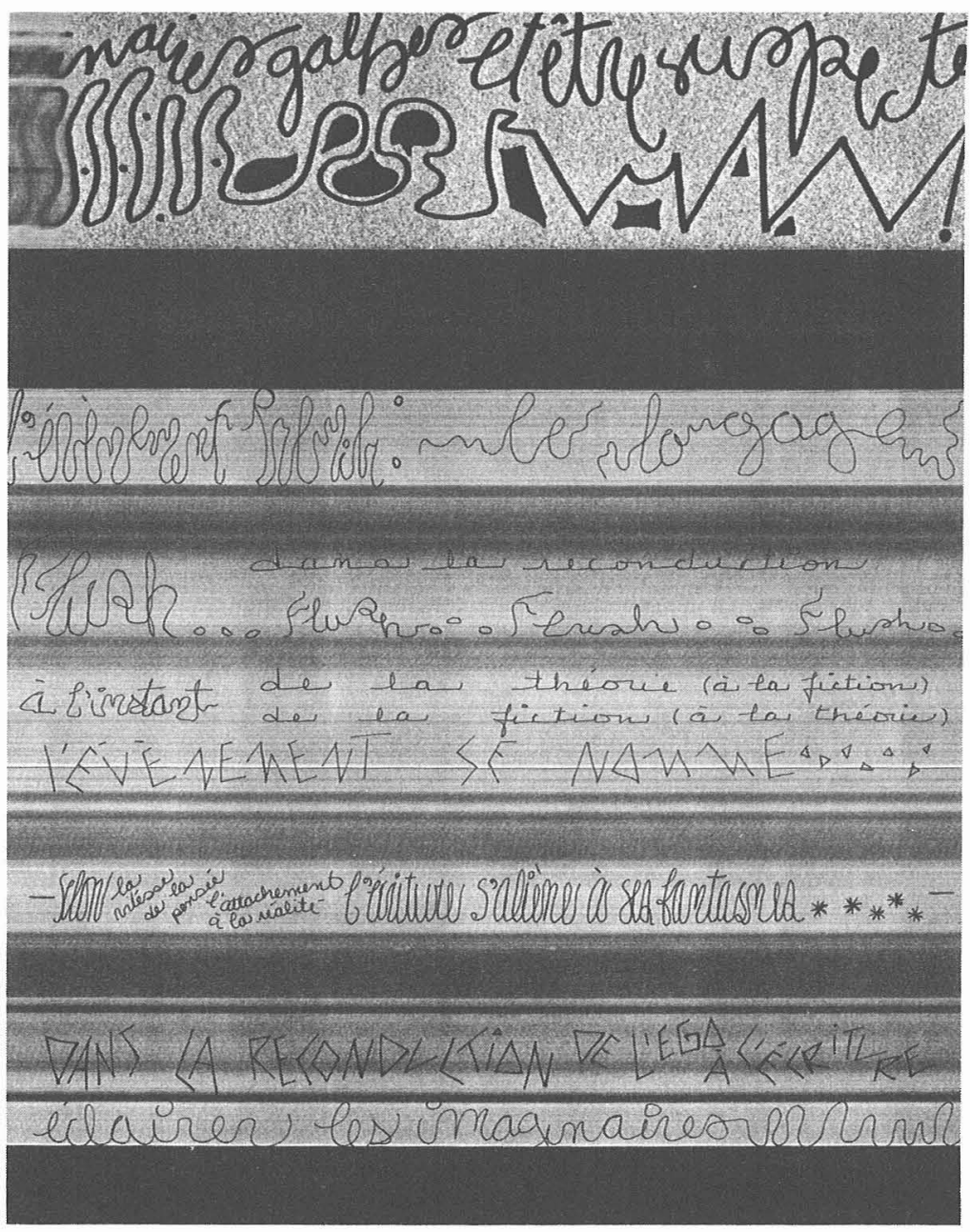

... inary curvaceously outlined and under suspicion / the initial occurence:

language / flux ... in the

(re)conversion ... flux ... flux ...

flux ... / at the very moment / of

theory (into fiction) / of fiction (into

theory) / this occurrence takes its name

...- according to the speed of the

thought the attachment to the reality

the written word is alienated by its

fantasies - in the conversion of the ego

into the written word / to illuminate

the imaginary 


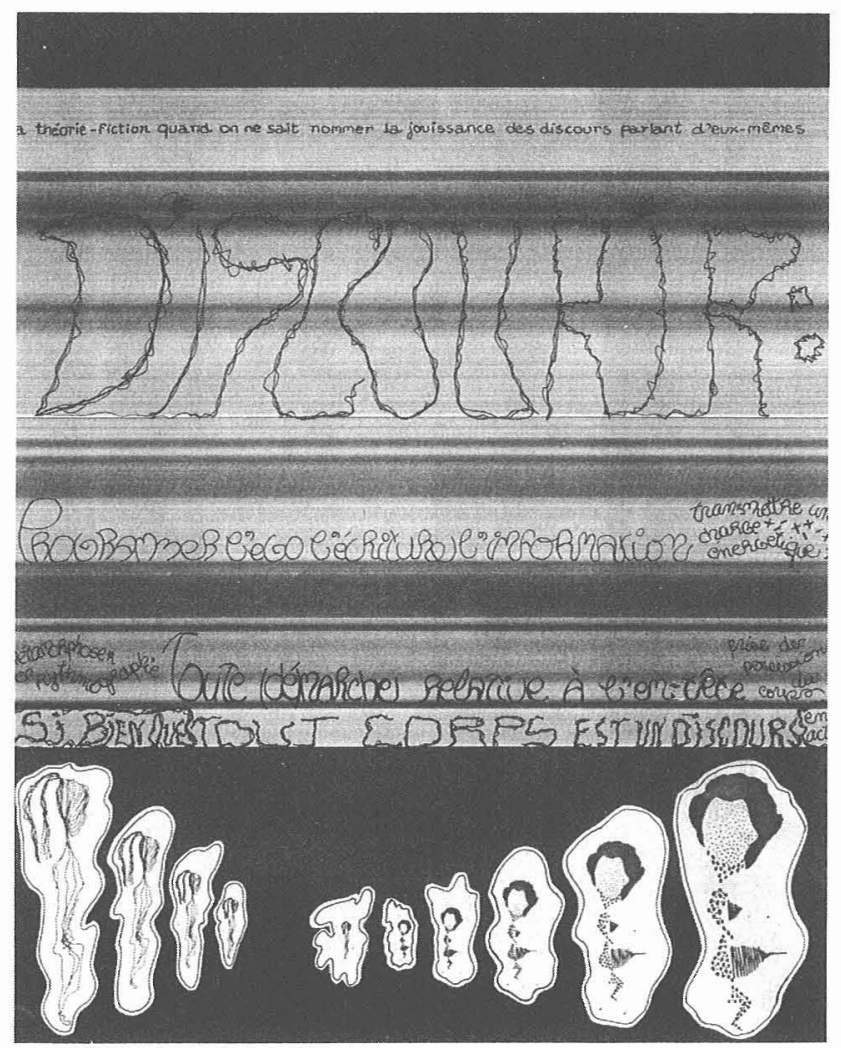

la théorie-fiction quand on ne sait nommer la jouissance des discours parlant d'eux-mêmes / DISCOURIR : programmer l'ego l'écriture l'information transmettre une charge énergétique / métamorphoser en rythmographie / toute démarche relative à l'entête / prise de possession du corps / si bien que tout corps est un discours en acte

theory-fiction when we don't know how to name the ecstasy derived from the inner eloquence of discourse / (TO) DISCOURSE: to program the ego the written word the information to transmit an energetic charge / to metamorphose into written rhythm / (a)head each step towards / seizing control of the body / in such a way that the entire body becomes a discourse (in)deed 


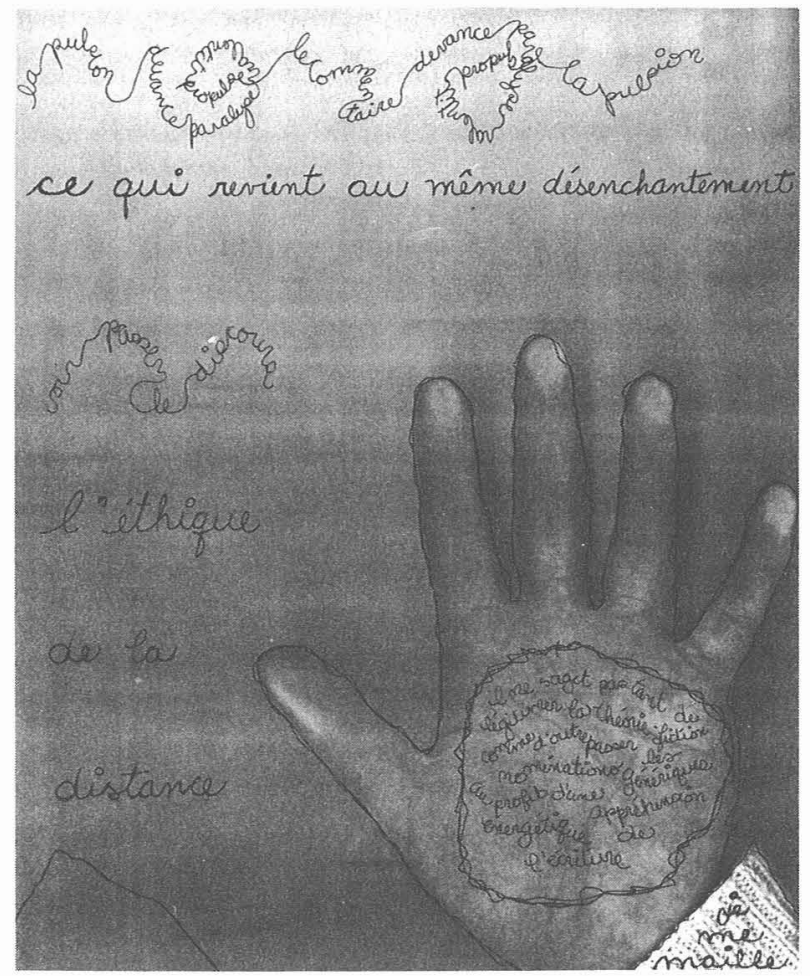

la pulsion devance paralyse ralentit propulse le commentaire devance paralyse ralentit propulse la pulsion / ce qui revient au même désenchantement / voir passer le discours / l'éthique de la distance / il ne s'agit pas tant de légitimer la théoriefiction comme d'outrepasser les nomination génériques au profit d'une appréhension énergétique de l'écriture / je me maille le corps...

the urge precedes paralyzes restrains propels the commentary precedes paralyzes restrains propels the urge / which amounts to the same disenchantment / watching the discourse pass by / distance as an ethic / it is not as much a question of legitimizing the theory-fiction as of going beyond the generic to the benefit of an energetic apprehension of the written word / my body's woven mesh 


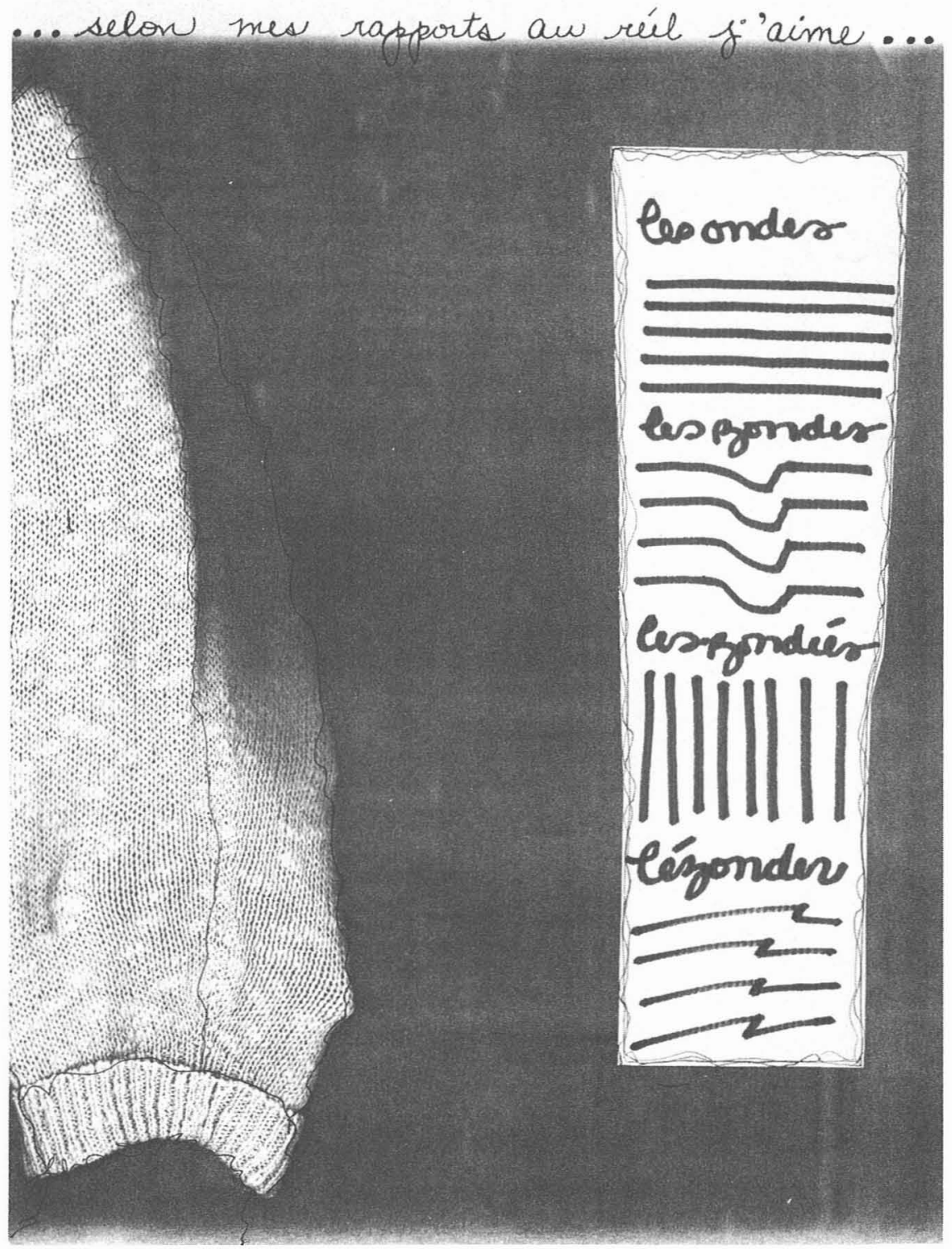

... selon mes rapports au réel j'aime ... / les ondes les zondes les zondées lézonder

according to my links to reality i love ... / the waves dewaves the waves dewaved dewaves waved 


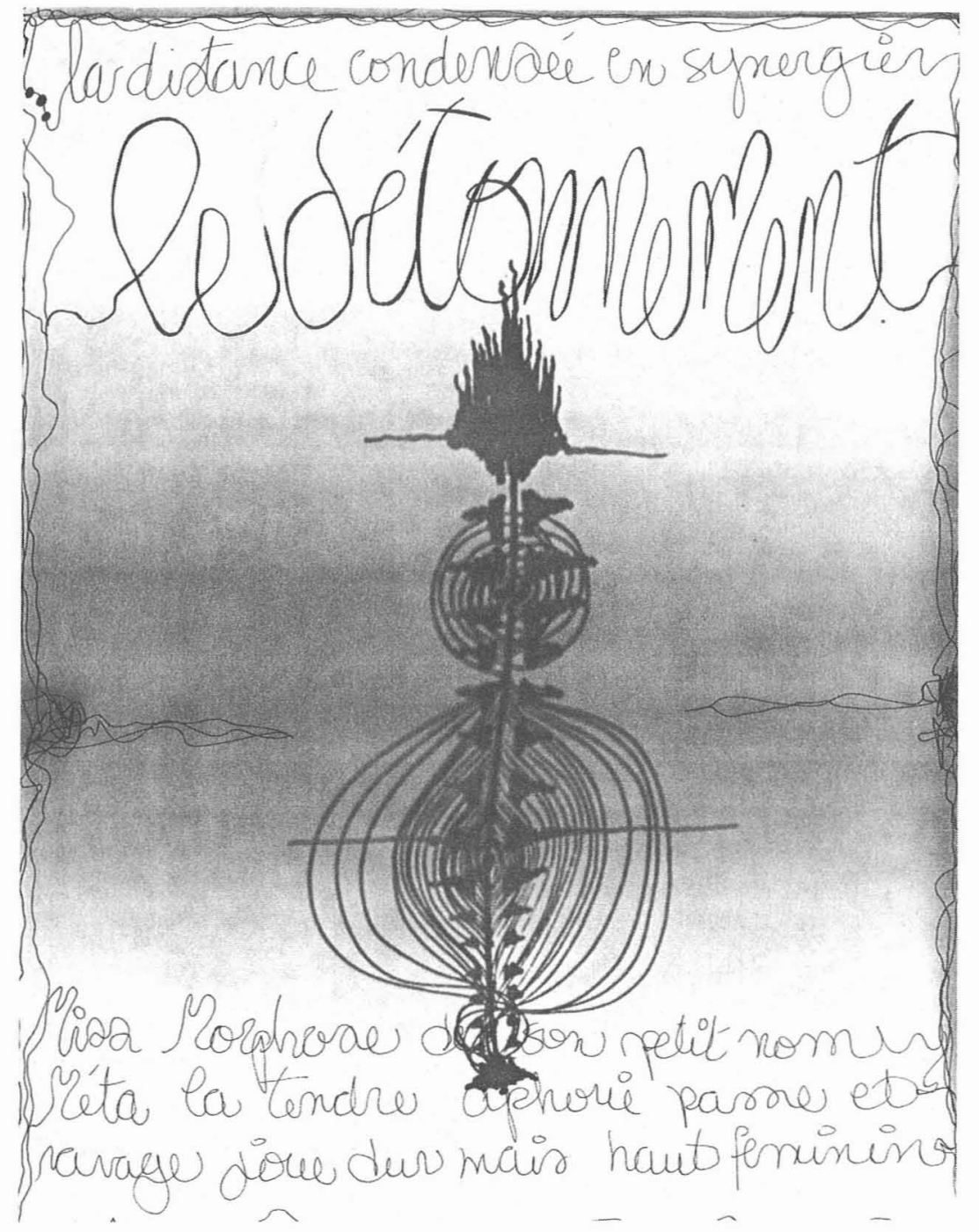

... la distance condensée en synergie / LE DÉTONNEMENT / Miss Morphose de son petit nom Méta la tendre aphorie passe et ravage joue dur mais haut féminin

... condensed distance synergetic /

CLASHSTOUNDING Miss Morphosis is her first name Meta the soft aphoria passing by ravages plays hard but feminine held high 


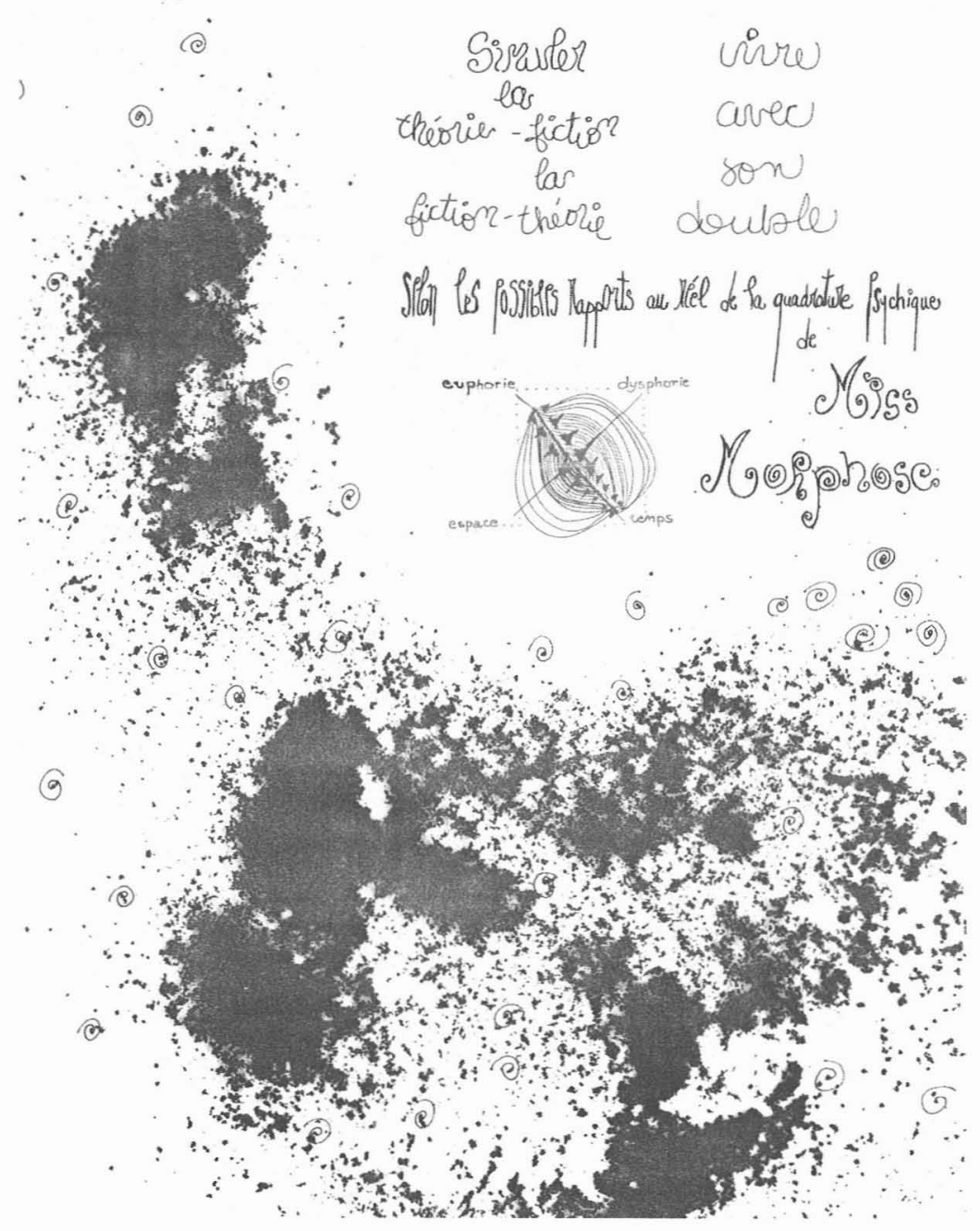

simuler la théorie-fiction la fiction-théorie / vivre avec son double / selon les possibles rapports au réel de la quadrature psychique de Miss Morphose / euphorie - dysphorie - espace temps

to simulate theory-fiction

double / according to the possible links to the reality of the psychic quadrature of Miss Metamorphosis / euphoria - dysphoria - space - time 


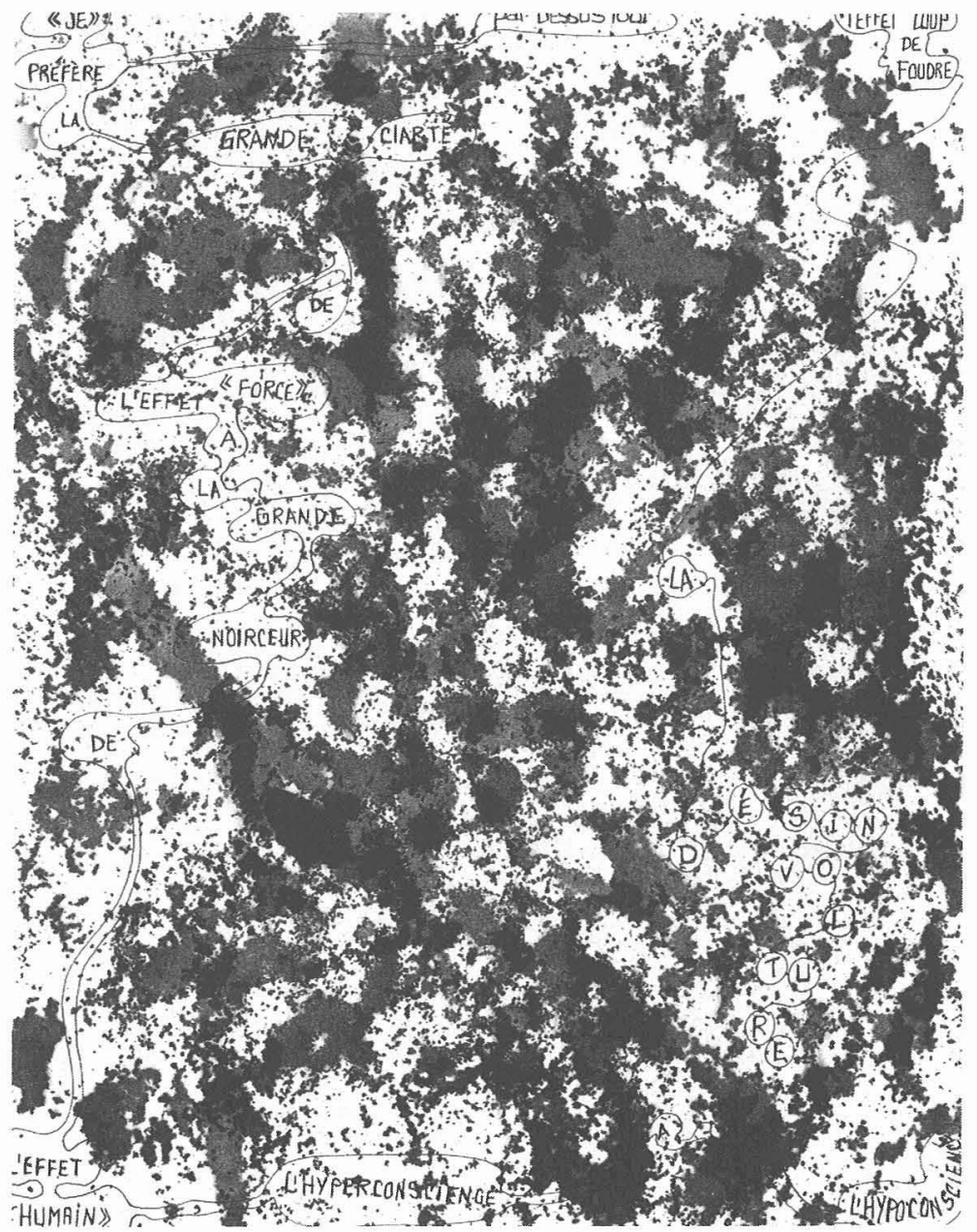

"je" / préfère / par dessus tout / la / grande / clarté / de / l'effet / "force" / à / la / grande / noirceur / de / l'effet / "humain" / l'hyperconscience / à / l'hypoconscience / l'effet coup de foudre / la / D / E / S / I / N / V / O / L / $\mathrm{T} / \mathrm{U} / \mathrm{R} / \mathrm{E}$

"i" / prefer / above all / the / great / clarity / of / "energy" / effect / to / the / great / darkness / of / "human" / effect / hyperconsciousness / to / hypoconsciousness / the thunderbolt effect / I / M / P / U / N / I / T / Y 
LINE McMURRAY, écrivaine et chercheure, membre du Collège de Pataphysique et du CRAIE (Centre de recherche et d'Analyse Intéractive en Ecriture, nbj), a publié des théories-fictions: Bluff (1983), Long Shot (1984), Le Torque (1985), La mort du genre (1985), ...Fictions as phyxion trans fixion (1985), Le détonnement (entretien avec Eugène Ionesco, 1985), Pour une éthique de la métamorphose (en collaboration avec Jean-Yves (ollette, 1986). Elle a travaillée à une théorie du genre Manifeste. L'enjeu du manifeste L.e manifeste en jeu (1986, avec Jeanne Demers). En préparation des textes qui questionnent les rapports sujet-calligraphie-choréographie-son-texte et l'écriture assistée par ordinateur.

LINE McMURRAY, writer and researcher, member of the College of Pataphysics and of CRAIE, has published fiction-theories: Bluff (1983), Long shot (1984), Le torque (1985), La mort du genre (1985), ... Fiction/as/phyxion/trans/fixion (1985), Le détonnement (interview with Eugene Ionesco, 1985), Pour une éthique de la métamorphose (with Jean-Yves Collete, 1986). She has been working in collaboration with Jeanne Demers on a theory of the Manifesto as genre, L'enjeu du manifeste/Le manifeste en jeu (1986). She is currently working on texts which interrogate the relations between subject-calligraphy-choreography-sound-text and on computer aided writing. 